\title{
Consumption of Goods
}

National Cancer Institute

\section{Source}

National Cancer Institute. Consumption of Goods. NCI Thesaurus. Code C66716.

The using or using up of goods and services, especially the rate at which they are used. 